\title{
Production of lettuce seedlings (Lactuca sativa) in granular rockwool and expanded perlite for use in hydroponics
}

\author{
Maria Luisa Tapia, and José Marcelo Caro \\ Facultad de Ciencias Agronómicas, Universidad de Chile, Santa Rosa 11315, La Pintana, Casilla 1004, \\ Santiago, Chile
}

\begin{abstract}
M.L. Tapia, and J.M. Caro. 2009. Production of lettuce (Lactuca sativa) seedlings in granulate rockwool and expanded perlite for use in hydroponics. Cien. Inv. Agr. 36(3):401410. The quality of lettuce (Lactuca sativa) seedlings is closely dependent on the substrate and the management practice during the transplant to the hydroponic system. This seed bed process may affect the normal development of the seedlings by affecting the post-transplanting period, potentially causing root stress, influencing establishment and even leading to seedling loss. An important criterion when choosing either a single or mixed substrate is the ability to provide for both growth and establishment of the seedlings in the hydroponic system. The main objective of this study was to evaluate the effect of granulated rockwool substrate (Agrolan ${ }^{\mathrm{TM}}$, Compañía Industrial El Volcán S.A., Santiago, Chile), expanded perlite A6 (Harbolite Chile Ltda., Santiago, Chile) and a mixture of both substrates on seedling growth, development and establishment after transplant of lettuce seedlings to an NFT-modified hydroponic system. Growth analyses were performed at the 2 to 3 true leaf stage of the lettuce seedlings, which were subsequently transferred to an NFT-modified hydroponic system. The stress level was evaluated at 10 days after transplant. From emergence until the 2 to 3 true leaf stage, no significant differences were observed between the assayed substrates. However, there was a consistent tendency for better growth development when seedlings were cultivated in the $100 \%$ rockwool substrate or in the substrate mixture containing rockwool in comparison to $100 \%$ expanded perlite. The differences obtained at seedling stages were maintained after seedlings were transplanted. The effect of the substrate was statistically significant $(p \leq 0.05)$ for all evaluated parameters 10 days after transplanting. These results confirmed that the rockwool substrate, alone or in combination with expanded perlite, allows for the production of high-quality lettuce seedlings that optimally respond to their establishment in an NFT-modified hydroponic system.
\end{abstract}

Key words: Hydroponic, Lactuca sativa, NFT-modified hydroponic, seedling bed, substrate, transplant stress.

\section{Introduction}

The success of lettuce (Lactuca sativa L.) and other vegetable production depends to a great

Received 4 Dec 2008. Accepted 4 May 2009. Corresponding author: mtapia@uchile.cl extent on seedling quality. This is particularly true for lettuce, because the seedling bed accounts for $30 \%$ of the overall production time (Kratky and Mishima, 1981; Incrocci et al., 2006). A good seedling for transplant must be vigorous, free of pests and diseases, and have a well-developed root system. Because transplant affects the growth rate, it is important to minimize stress and maintain continuous growth 
(Vavrina, 2004). The time for the plant to overcome transplant stress and become established depends on the species, cultivar, environmental conditions, crop system, transplant management, and seedling quality (Tapia et al., 2007, 2008). The time required to form new roots and reestablish their normal development is also species dependant (Waine, 2003).

The substrate used for the seedling bed is of great importance in order to produce high-quality seedlings (Gruda, 2009). The optimal result occurs when seedlings are transplanted with the substrate attached to the roots, forming a root ball without disintegration (Alvarado and Rojas, 1996). Lettuce seedlings produced in substrates that allowed for optimal aggregation at transplanting always reached a higher growth rate than those with desintegrations (Aillapan, 1997).

Some chemically inert substrates offer advantages over traditional substrates used in seedling production, because they act only as a plant support, without affecting the nutrient adsorption process and/or nutrient fixation (Cave, 1991). Of the most commonly used inert substrates worldwide, rockwool and expanded perlite stand out, because they both have $\mathrm{pH}$ values close to neutral and null cationic exchange capacities (CEC) (Cantliffe, 2008). Rockwool and perlite offer a high degree of water capillary movement and a large space for air distribution (Hochmuth and Hochmuth, 1998).

Humidity and the substrate water content play fundamental roles in root and aerial growth (Nicola et al., 2004). Rockwool is one of the most studied and useful substrates; it is a highly porous inert material with a homogeneous structure and free of pathogens. Over $95 \%$ of the water retained by rockwool is readily available to seedlings (Abad, 1993; Benko et al., 2008). In Chile, Compañía Industrial El Volcán S.A. (Santiago, Chile) produces Agrolan $^{\circledR}$, a substrate similar to granular rockwool; however, there is no scientific information supporting the potential of this substrate in lettuce seedlings for hydroponic cultivation or for the production of other vegetable seedlings.

On the other hand, expanded perlite retains water only in the particles at the surface or in between pores, and therefore is commonly used in combination with other substrates to increase aeration. Only $25 \%$ of the retained water is readily available for seedlings (Abad, 1993). Lettuce seedlings produced in expanded perlite are reported to have a low growth rate at 20 days post-transplant (Aillapan, 1997), mainly because of the disintegration of the perlite root ball when transplanting, thereby delaying the seedling growth.

Acosta (1996) worked with rockwool, perlite and a mixture of perlite and peat in greenhouse tomato. Based on evaluations performed at different growth stages after transplant, the plants growing in rockwool were always reported to grow better than those in perlite. Significant differences in the number of leaves per plant, plant height and fruit fresh weight were also found (Acosta, 1996).

On the other hand, Martínez and Abad (1992) studied the behavior of tomato plants in seven different substrates, and found that plant height, anthesis, fruit set, and formed fruits evaluated 8 and 13 weeks post-transplant were higher in tomatoes established in rockwool than in perlite. However, the early yield was statistically similar in both substrates, and the total fruit yield was slightly higher in tomatoes established in perlite than in other substrates. Benko et al. (2008), in a two-year trial, obtained significantly higher yields in tomato plants cultivated in rockwool than in expanded clay.

The selection of substrate type has been studied in numerous plant species, yielding different results between them, even among cultivars of the same species. However, information is scarce with respect to the plant response to establishment in hydroponic systems. Furthermore, the available information is difficult to adapt to the chilean conditions. Preliminary observations suggest that Agrolan $^{\circledR}$ would allow for the production of high-quality lettuce seedlings with better establishment in hydroponic systems than with expanded perlite. Therefore, the objective of this study was to evaluate the growth and development of lettuce seedlings produced in granular rockwool, expanded perlite and mixtures of both substrates during the seedling bed phase and to investigate their fur- 
ther establishment in an NFT-modified hydroponic system.

\section{Materials and methods}

\section{Inert substrates used}

The study was conducted in La Pintana, Santiago, Chile (32 $40^{\prime}$ ' S, $70^{\circ} 32^{\prime}$ W, 625 m.a.s.1.) using lettuce ( $L$. sativa var. capitata) cv. Divina. This is an early lettuce cultivar, greasy, with smooth green leaves. Two chemically inert substrates were studied in different proportions: a. $100 \%$ granular rockwool $\left(\right.$ Agrolan $^{\circledR}$, Compañía Industrial El Volcan S.A., Santiago, Chile), b. 100\% expanded perlite A6 (Harborlite Chile Ltda. Santiago, Chile), c. $75 \%$ (v/v) Agrolan ${ }^{\circledR}$ in combination with $25 \%(\mathrm{v} / \mathrm{v})$ expanded perlite, d. $50 \%$ $(\mathrm{v} / \mathrm{v})$ Agrolan $^{\circledR}$ in combination with $50 \%(\mathrm{v} / \mathrm{v})$ expanded perlite, and $25 \%(\mathrm{v} / \mathrm{v})$ Agrolan $^{\circledR}$ in combination with $75 \%(\mathrm{v} / \mathrm{v})$ expanded perlite.

\section{Seedling bed}

Tests were carried out in a greenhouse covered with black mesh with $65 \%$ light interference. Lettuce was seeded on Protekta ${ }^{\circledR}$ trays (Protekta Ltda., Santiago, Chile) and each was provided with 162 cups each of $16 \mathrm{~mL}$. A table for capillary irrigation, which was covered with a lowdensity polyethylene (150 $\mu \mathrm{m}$ thick), was used. Irrigation was performed by daily applying a water sheet to allow for a complete wetting of each substrate according to its retention capacity.

Fertilization began when seedlings had expanded cotyledons using a nutrient solution composed of (per liter): $125 \mathrm{mg} \mathrm{N}, 60 \mathrm{mg} \mathrm{P}, 160 \mathrm{mg}$ $\mathrm{Ca}, 38 \mathrm{mg} \mathrm{Mg}, 0.5 \mathrm{mg} \mathrm{Fe}, 0.22 \mathrm{mg} \mathrm{B}, 0.03 \mathrm{mg}$ $\mathrm{Cu}, 0.03 \mathrm{mg} \mathrm{Mo}, 0.05 \mathrm{mg} \mathrm{Zn}, 0.31 \mathrm{mg} \mathrm{Mn}$ and $16.14 \mathrm{mg} \mathrm{S}$. A 50\% nutrient solution was delivered by capillary every two days.

In order to characterize the amount of time for seedling development in each treatment, the number of degree days was recorded, from seeding to emergency, seeding to expanded cotyledons, seeding to first expanded true leaf, and seeding to the two to three true leaf stage (phenological stage at transplanting). At each of these phenological stages of seedling development, 42 seedlings were taken at random from each replicate and the number of seedlings at each stage was calculated. To estimate the degree days (DD), the daily minimum and maximum temperatures were recorded at the plant height to determine the daily mean temperature $(\mathrm{T})$ and then subtracted by the temperature threshold (Tt) of lettuce growth $\left(\mathrm{Tu}=5^{\circ} \mathrm{C}\right)(\mathrm{Gia}$ coni and Escaff, 2001).

\section{Transplant}

Seedling vigor was evaluated at the transplanting stage (seedling with 2 to 3 true leaves) to determine the plant height (distance from the plant neck to the apex of the tallest leaf), leaf area using a LI-COR ${ }^{\circledR}$ leaf area meter (LI-3000A model, LI-COR Biosciences, Lincoln, NE, USA), aerial fresh weight and dry weight (dried at $70^{\circ} \mathrm{C}$ to a constant weight in a Labtech stove, Daihan Labtech Co., Ltd., Namyangju, South Korea).

\section{Post-transplant establishment}

Transplanting was done when $80 \%$ of the lettuce seedlings were at the 2 to 3 true leaf stage. Five seedlings per replicate were taken randomly and arranged in an NFT-modified system, with a $25-\mathrm{cm}$ plantation frame over and among the polyvinyl chloride profiles (PVC). A 2\% slope and a $0.5-1.0 \mathrm{~mm}$ high-nutrient lamina were provided.

The nutrient solution was stored in darkness in a PVC tank and was driven by a Pedrollo Model PKm $60^{\circledR}$ pump (Pedrollo, S.p.A., Verona, Italy) with a $5.4 \mathrm{~m}^{3} \mathrm{~h}^{-1}$ flow rate. The entrance of the nutrient solution to the hydroponic system was regulated through a source valve, with an average flow of $0.7 \mathrm{Lmin}^{-1}$, which was measured in the discharge head of each profile.

In a traditional NFT system, the seedlings are 
established on bare roots in the absence of a substrate. However, we used a modified NFT hydroponic system where the root ball formed by the roots and the substrate was kept in order to hinder alterations to the root system and to reduce the post-transplant stress. A seedling was set in each profile hole, which was fixed by a low-density expanded polyurethane cube that was placed at the plant neck. At 10 days post-transplant, the plant height, foliar area, fresh weight and dry weight of the aerial portion and the total number of leaves per plant were recorded. In addition, the number of lost plants and the post-transplant establishment percentage were determined.

\section{Design and statistical analysis}

A completely randomized block design was performed with five treatments and five replicates. The experimental unit in the seedling bed period was the 162 alveoli tray, with a sampling unit of 42 seedlings. In the NFT-modified system, the experimental unit consisted of five plants per replicate and the sampling unit comprised four plants. The results obtained were subject to an analysis of variance (ANOVA) and the means were separated using the Student Newman-Keuls (SNK) multiple range comparison test ( $p \leq 0.05)$. The number of leaves per plant and percentage data were transformed as $\sqrt{ }\left(n^{\circ}\right.$ of leaves +1$)$ and arccosine $\sqrt{ }(\%$ establishment $)$, respectively, before the ANOVA (Montgomery, 1991).

\section{Results}

\section{Seedling development}

The use of expanded perlite, granular rockwool or the mixtures of both substrates did not significantly affect the development of lettuce seedlings, as measured by the seeding emergence and later at the expanded cotyledon and 2 to 3 true leaf stages (Table 1).

Table 1. Lettuce (Lactuca sativa) seedlings at emergency, expanded cotyledons, and at the one to two true leaf stage.

\begin{tabular}{|c|c|c|c|c|}
\hline \multicolumn{5}{|c|}{ Seedlings development at the bed stages } \\
\hline Substrate treatments ${ }^{1}$ & $\begin{array}{l}\text { Emergency } \\
\%\end{array}$ & $\begin{array}{l}\text { Expanded cotyledons } \\
\%\end{array}$ & $\begin{array}{l}1-2 \text { true } \\
\text { leaf stage } \\
\%\end{array}$ & $\begin{array}{l}2 \text { true leaf stage } \\
\%\end{array}$ \\
\hline Rockwool, $100 \%$ & $87.60^{\mathrm{ns}}$ & $87.14^{\mathrm{ns}}$ & $86.19^{\text {ns }}$ & $85.23^{\mathrm{ns}}$ \\
\hline $\begin{array}{l}\text { Rockwool, } 75 \% \\
+ \text { perlite, } 25 \%\end{array}$ & 86.19 & 84.76 & 91.42 & 84.28 \\
\hline $\begin{array}{l}\text { Rockwool, } 50 \% \\
+ \text { perlite } 50 \%\end{array}$ & 91.42 & 90.95 & 92.38 & 88.09 \\
\hline $\begin{array}{l}\text { Rockwool, } 25 \% \\
+ \text { perlite, } 75 \%\end{array}$ & 88.57 & 92.85 & 88.57 & 90.00 \\
\hline Perlite, $100 \%$ & 88.57 & 87.14 & 91.42 & 74.76 \\
\hline Time, days & 7 & 11 & 16 & 21 \\
\hline Degree days $^{3}$ & 105.5 & 159.0 & 215.5 & 313.7 \\
\hline
\end{tabular}

${ }^{1}$ Agrolan ${ }^{\circledR}$ Rockwool (Compañía Industrial El Volcan S.A., Santiago, Chile). Perlite corresponds to expanded perlite A6 (Harborlite Chile Ltda. Santiago, Chile).

${ }^{2} \mathrm{~ns}$, not significantly different according to the SNK test $(\mathrm{p} \leq 0.05)$.

${ }^{3}$ To estimate the degree days (DD), the daily minimum and maximum temperatures were recorded at plants height to determine the daily mean temperature $(\mathrm{T})$ and then subtracted by the temperature threshold $(\mathrm{Tt})$ of lettuce growth $\left(\mathrm{Tu}=5^{\circ} \mathrm{C}\right)$.

\section{Evaluation of seedlings on transplant}

Fresh weight and dry weight. A significant effect of the substrates was observed on the aerial fresh and dry weights, which were lower for lettuce plants cultivated in 100\% expanded perlite than in substrates containing granular rockwool. No statistical differences were obtained among the four substrate treatments where granular rockwool was present (Table 2). 
Table 2. Characteristics of lettuce (Lactuca sativa) seedlings obtained in different substrates.

\begin{tabular}{|c|c|c|c|c|c|}
\hline $\begin{array}{l}\text { Substrate } \\
\text { treatments }^{1}\end{array}$ & $\begin{array}{l}\text { Fresh weight/ plant } \\
\mathrm{g}\end{array}$ & $\begin{array}{l}\text { Dry weight }{ }^{2} / \\
\text { plant } \\
\text { g }\end{array}$ & $\begin{array}{l}\text { Height/ } \\
\text { plant } \\
\mathrm{cm}\end{array}$ & $\begin{array}{l}\text { Foliar } \operatorname{area}^{3} / \\
\text { plant } \\
\mathrm{cm}^{2}\end{array}$ & $\begin{array}{l}\text { Leaves/ } \\
\text { plant } \\
\text { no. }\end{array}$ \\
\hline & \multicolumn{5}{|l|}{2 to 3 true leaf stage } \\
\hline Rockwool, $100 \%$ & $0.235 b^{4}$ & 0.018 & $5.88 \mathrm{~b}$ & $11.09 \mathrm{~b}$ & \\
\hline $\begin{array}{l}\text { Rockwool, } 75 \% \\
+ \text { perlite, } 25 \%\end{array}$ & $0.224 \mathrm{~b}$ & $0.017 \mathrm{~b}$ & $5.75 b$ & $9.45 \mathrm{ab}$ & \\
\hline $\begin{array}{l}\text { Rockwool, } 50 \% \\
+ \text { perlite, } 50 \%\end{array}$ & $0.230 \mathrm{~b}$ & $0.017 \mathrm{~b}$ & $5.70 \mathrm{~b}$ & $10.73 \mathrm{~b}$ & \\
\hline $\begin{array}{l}\text { Rockwool, } 75 \% \\
+ \text { perlite, } 25 \%\end{array}$ & $0.248 \mathrm{~b}$ & $0.017 \mathrm{~b}$ & $5.23 \mathrm{~b}$ & $9.31 \mathrm{ab}$ & \\
\hline \multirow[t]{2}{*}{ Perlite, $100 \%$} & $0.162 \mathrm{a}$ & $0.011 \mathrm{a}$ & $4.29 \mathrm{a}$ & $6.58 \mathrm{a}$ & \\
\hline & \multicolumn{5}{|c|}{10 days after transplant } \\
\hline Rockwool, $100 \%$ & $1.670 \mathrm{~b}^{4}$ & $0.138 \mathrm{~b}$ & $9.2 b c^{1}$ & $50.4 \mathrm{~b}$ & $5.86 \mathrm{ab}$ \\
\hline $\begin{array}{l}\text { Rockwool, } 75 \% \\
+ \text { perlite, } 25 \%\end{array}$ & $1.470 \mathrm{~b}$ & $0.124 \mathrm{~b}$ & $8.2 \mathrm{~b}$ & $36.6 \mathrm{ab}$ & $5.79 \mathrm{ab}$ \\
\hline $\begin{array}{l}\text { Rockwool, } 50 \% \\
+ \text { perlite, } 50 \%\end{array}$ & $1.740 \mathrm{~b}$ & $0.151 \mathrm{~b}$ & $9.5 \mathrm{c}$ & $49.5 \mathrm{~b}$ & $6.13 \mathrm{~b}$ \\
\hline $\begin{array}{l}\text { Rockwool, } 75 \% \\
+ \text { perlite, } 25 \%\end{array}$ & $1.440 \mathrm{~b}$ & $0.125 \mathrm{~b}$ & $8.8 \mathrm{c}$ & $40.1 \mathrm{ab}$ & $5.66 \mathrm{ab}$ \\
\hline Perlite, $100 \%$ & $0.800 \mathrm{a}$ & $0.069 \mathrm{a}$ & $6.7 \mathrm{a}$ & $25.0 \mathrm{a}$ & $5.13 \mathrm{a}$ \\
\hline
\end{tabular}

${ }^{1}$ Agrolan ${ }^{\circledR}$ Rockwool (Compañía Industrial El Volcan S.A., Santiago, Chile). Perlite corresponds to expanded perlite A6 (Harborlite Chile Ltda. Santiago, Chile).

${ }^{2}$ Dry weight was determined at constant weight at $70^{\circ} \mathrm{C}$ in a Labtech stove (Daihan Labtech Co., Ltd., Namyangju, South Korea). ${ }^{3}$ Foliar area was determined with an LI-COR foliar area integrator (model LI-3000A, LI-COR Biosciences, Lincoln, NE, USA).

${ }^{4}$ Means followed by the same letters in each column are not statistically different according to the SNK test $(\mathrm{p} \leq 0.05)$.

Seedlings height. The effect of substrates was also significant for differences in seedling height obtained at the 2 to 3 true leaf stage. Lettuce seedling heights varied from $5.88 \mathrm{~cm}$ as the average for seedlings produced in $100 \%$ granular rockwool to $4.29 \mathrm{~cm}$ in $100 \%$ expanded perlite. The seedlings produced in $100 \%$ expanded perlite were significantly shorter than in other substrates. The four treatments including granular rockwool were statistically similar in plant height (Table 2).

Foliar area. The effect of substrates was significant for differences in foliar area obtained at the 2 to 3 true leaf stage. Foliar area varied from $11.09 \mathrm{~cm}^{2}$ for seedlings produced in $100 \%$ granular rockwool to $6.58 \mathrm{~cm}^{2}$ in $100 \%$ expanded perlite (Table 2).

\section{Post-transplant evaluation}

Independent of the seedling bed substrate, $100 \%$ establishment was obtained in the NFT- modified hydroponic system at 10 days after transplant. The plants remained turgid and free of chlorosis or other symptoms due to stress because of the transplant.

Fresh weight and dry weight. The lettuces had considerably increased fresh and dry weights in the NFT-modified hydroponic system 10 days after transplant for all substrate treatments. Lettuce produced in $100 \%$ expanded perlite had the lowest aerial weights; however, a 6-times dry weight increase was obtained in only 10 days. In contrast, lettuce cultivated in a mixture of $50 \%$ granular rockwool and $50 \%$ expanded perlite showed an 8.72-times weight gain on average. Significant effects of the substrates on the fresh and dry weights were observed, and plants produced in $100 \%$ expanded perlite had significantly lower weights than in substrates containing rockwool (Table 2).

Plant height. Ten days after transplant, plant height increased more than $44 \%$ compared to the time of transplant in all substrate treatments. Lettuce plants produced in 50\% granular rock- 
wool in combination with $50 \%$ expanded perlite reached the highest height, $9.5 \mathrm{~cm}$ on average and had the largest height increase (66\%). Although the plants produced in $100 \%$ expanded perlite had the lowest average height $(6.7 \mathrm{~cm})$, these plants had a $57 \%$ increase in plant height over the 10 days after transplant (Table 2).

Foliar area. Foliar area also increased considerably in the 10 days after transplant for all substrate treatments, up to $370 \%$ more than at transplanting. The plants developed in $100 \%$ granular rockwool had a foliar area of $50.4 \mathrm{~cm}^{2}$ after ten days, which is almost $100 \%$ more than the $25 \mathrm{~cm}^{2}$ foliar area of plants produced in $100 \%$ expanded perlite. The effects of substrate on foliar area are shown in Table 2.

Number of leaves. No leaf loss was observed after 10 days of transplant in the lettuce plants for any of the substrate treatments. An average of 5.71 leaves per plant was produced in each of the five substrates, which represented an increase of nearly three new leaves per plant in 10 days. The effects of substrate on the numbers of leaves are shown in Table 2.

\section{Discussion}

At transplant (2 to 3 true leaf stage), lettuce seedlings produced in the substrates containing a high proportion of granular rockwool developed a root ball with the substrate attached to the roots in contrast to the disaggregation obtained in seedlings produced in $100 \%$ expanded perlite (Figure 1A). This difference may be due to a higher capacity of water retention of rockwool $(80 \%)$ in comparison to expanded perlite $(73 \%)$, which allows for a stronger union between the substrate particles and roots (Table 3).

Table 3. Chemical and physical characteristics of the five substrate treatments studied for lettuce (Lactuca sativa) seedling production.

\begin{tabular}{|c|c|c|c|}
\hline \multirow[b]{2}{*}{ Treatments $^{1}$} & \multicolumn{3}{|c|}{$\begin{array}{c}\text { Chemical and physical } \\
\text { characteristics }^{2}\end{array}$} \\
\hline & $\mathrm{pH}$ & $\begin{array}{l}\text { Electric } \\
\text { conductivity } \\
\mathrm{dSm}^{-1}\end{array}$ & $\begin{array}{l}\text { Humidity } \\
\%\end{array}$ \\
\hline Rockwool, 100\% & 7.6 & 0.5 & 80 \\
\hline $\begin{array}{l}\text { Rockwool, } 75 \% \\
+ \text { perlite, } 25 \%\end{array}$ & 8.0 & 0.5 & 79 \\
\hline $\begin{array}{l}\text { Rockwool, } 50 \% \\
+ \text { perlite, } 50 \%\end{array}$ & 8.0 & 0.5 & 79 \\
\hline $\begin{array}{l}\text { Rockwool, } 25 \% \\
+ \text { perlite, } 75 \%\end{array}$ & 8.0 & 0.4 & 78 \\
\hline Perlite, $100 \%$ & 8.0 & 0.3 & 73 \\
\hline
\end{tabular}

${ }^{1}$ Agrolan ${ }^{\circledR}$ Rockwool (Compañía Industrial El Volcan S.A., Santiago, Chile). Perlite corresponds to expanded perlite A6 (Harborlite Chile Ltda. Santiago, Chile).

${ }^{2}$ Analysis done in Agricultural Laboratory AGROLAB (AGROLAB Ltda., Santiago, Chile).

The fast weight gain and higher production of dry matter of seedlings produced in substrates containing rockwool may be attributed to the high degree of aggregation provided by this substrate, which allowed the seedling to adapt faster to the new environment and to optimally reduce the post-transplant stress.

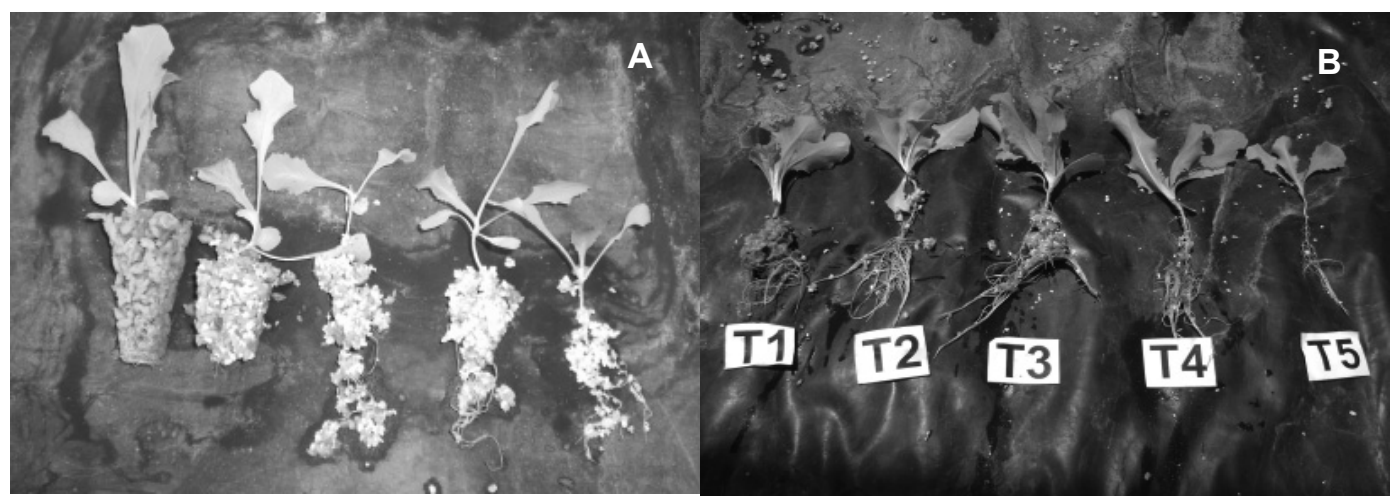

Figure 1. Lettuce seedlings (Lactuca sativa). A. Seedlings at the 2 to 3 true leaf stage (transplant stage). From left to right: T1 (Rockwool, 100\%); T2 (Rockwool, 50\% + Perlite, 50\%); T3 (Rockwool, 50\% + Perlite 50\%); T4 (Rockwool, 25\% + Perlite, $75 \%)$; T5 (Perlite, 100\%). B. Lettuce plants ten days post-transplant in an NFT-modified hydroponic system. 
The relatively low height of the lettuce seedlings produced in expanded perlite can be explained by the lower capacity for water retention (73\%) and the relatively low water availability as only $25 \%$ of this retention is readily available for the plant. As such, it is possible that the seedlings were under water restrictions that affected their normal growth development. In addition, the low degree of aggregation of expanded perlite did not allow for the formation of a root ball with the root system, thus producing root malformations at transplanting. According to Waine (2003), this root malformation may negatively affect seedling establishment and loss of crop precocity, restricting the aerial growth of the plant. Root stresses can cause inhibition of cytokinin and gibberellin translocation from the roots to the aerial organs, enhancing the levels of abscisic acid and ethylene production, and leading to a growth regulator imbalance that can restrict plant growth (Sharp, 2002; Leskovar et al., 2008).

The fast increase of the foliar area in the seedlings where rockwool was present confirms the same tendency recorded in measurements of the other growth parameters. The high degree of aggregation from this substrate helped to maintain the active growth and development of the plant at transplanting. According to Cometti et al. (2004), plants cultivated in hydroponics have a lower amount of assimilates (dry matter) in the formation of stems and central leaves ribs, thereby increasing their foliar lamina. On the other hand, plants cultivated in soil make a higher use of carbon hydrates during root growth in comparison to those established in hydroponic systems. Therefore, plants cultivated in hydroponic media grow and develop more efficiently than in soil.

Within hydroponic cultivation systems, the NFT and NFT-modified systems favor successful establishment of seedlings. The flow rate of the nutritive lamina is higher than the absorption rate of the plants, ensuring the water and nutritional supply and hindering excessive root growth (Molyneux, 1988). This becomes more relevant during the first days post-transplant; therefore, the adaptation period depends on the general environmental conditions of the seedling to continue its normal development. Consequently, one of the greatest advantages of the NFT and NFT-modified systems is the constant supply of nutrients, which helps to maintain optimal plant growth (Graves, 1983; Waine, 2003; Gruda, 2009).

This investigation provided unprecedented information about the growth and development of lettuce seedlings in inert substrates and their further establishment in a hydroponic NFTmodified system. Our results demonstrated that the rockwool substrate, alone or in combination with expanded perlite, is appropriate for the production of high-quality lettuce seedlings in NFT-modified hydroponic systems. Farmers dedicated to hydroponic lettuce production will gain from this information, as they are currently obligated to purchase seedlings produced in conventional substrates, which requires washing the root mass to eliminate the adhered substrates and ultimately results in root loss, posttransplant stress and premature plant aging. 


\section{Resumen}

M.L. Tapia y J.M. Caro. 2009. Producción de plantines de lechuga (Lactuca sativa) en lana de roca granulada y perlita expandida para uso en hidroponía. Cien. Inv. Agr. 36(3):401410. La calidad final de un plantín depende estrechamente del sustrato empleado y del manejo realizado durante el transplante al sistema hidropónico. Este proceso puede afectar negativamente el desarrollo posterior de los plantines, alterando el periodo de postransplante, debido que provoca estrés a nivel radical, que genera pérdidas por problemas en el establecimiento de los plantines. Un criterio importante para elegir un sustrato, ya sea sólo o en mezcla, es asegurar la continuidad del crecimiento y el establecimiento de los plantines en el sistema hidropónico. El objetivo de esta investigación fue evaluar los efectos de lana de roca granulada (Agrolan ${ }^{\circledR}$, Compañía Industrial El Volcán S.A., Santiago, Chile), perlita expandida A6 (Harbolite Chile Ltda., Santiago, Chile) y mezcla de ambos sustratos sobre el crecimiento, desarrollo y posterior establecimiento de plantines de lechuga (Lactuca sativa L.) en un sistema hidropónico NFTmodificado. Los análisis de crecimiento se realizaron cuando los plantines estaban en el estado de $2^{\mathrm{a}}$ a $3^{\mathrm{a}}$ hoja verdadera y posteriormente se procedió al establecimiento de ellas en un sistema hidropónico NFT-modificado con el objetivo de evaluar el estrés 10 días post transplante. En la primera etapa del desarrollo de los plantines (desde la emergencia hasta el transplante) no se observaron diferencias significativas en los sustratos utilizados. Pero consistentemente se obtuvo una tendencia de un mayor crecimiento de los plantines cuando el sustrato era $100 \%$ lana de roca y tambien con las distintas mezclas de este sustrato, en comparación con los resultados obtenidos al emplear $100 \%$ perlita expandida. Esta diferencia se mantuvo después del transplante. El efecto del sustrato empleado fue estadísticamente significativo $(\mathrm{p} \leq 0.05)$ en todos los parámetros evaluados 10 días post transplante. Confirmándose nuevamente que el sustrato lana de roca (sólo o en mezcla con perlita expandida) permitió producir plantines de lechuga de calidad, los que responden de forma óptima al establecimiento en un sistema hidropónico NFT-modificado.

Palabras clave: Almácigo, estrés post transplante, hidroponía, Lactuca sativa, NFT-modificado, sustrato.

\section{References}

Abad, M. 1993. Sustrato. Páginas 47-65. En: F. Canóvas and J.R. Díaz (eds.). Cultivos Sin Suelos. Instituto de Estudios Almerienses. Almería, España.

Acosta, C. 1996. Uso de lana de roca como sustrato hidropónico en el cultivo de tomate bajo invernadero. Memoria Ingeniero Agrónomo. Facultad de Agronomía, Pontificia Universidad Católica de Chile. Santiago, Chile. 66 pp.

Aillapan, E. 1997. Evaluación de sustratos para la preparación industrial de plantines hortícolas. Memoria Ingeniero Agrónomo. Facultad de Ciencias Agronómicas. Universidad de Chile, Santiago, Chile. 70 pp.

Alvarado, P., and R. Rojas. 1996. Producción comercial de plantines libres de estrés. Agroeconómico (Chile) 34:6-13. 
Benko, B., J. Borošić, B. Novak, N. Toth, M. Žutić and M. Romić. 2008. Tomato yield dependent on substrate type and volume. Acta Horticulturae 779: 455-459.

Cantliffe, D.J. 2008. Plug transplant technology. Horticultural Reviews 35:397-436.

Cave, C. 1991. The effect of intermittent irrigation with cold nutrient solution on the growth of tomato seedlings propagated in rockwool. Journal of Horticultural Science 66:781-788.

Cometti, N., G. Matías, E. Zonta, W. Mary, and M. Fernandes. 2004. Compostos nitrogenados e açúcares solúveis em tecidos de alface orgánica, hidropónica e convencional. Horticultura Brasileira. 22(4):748-753.

Giaconi, V., and M. Escaff. 2001. Cultivo de Hortalizas, $15^{\mathrm{a}}$ Ed. Editorial Universitaria, Santiago de Chile. 337 pp.

Graves, C. 1983. The nutrient film technique. Horticultural Reviews 5:1- 44

Gruda, N. 2009. Do soilless culture systems have an influence on product quality of vegetables?. Journal of Applied Botany and Food Quality. 82:141-147.

Hochmuth, G., and R. Hochmuth, 1998. Nutrient solution formulation for hydroponic (perlite, rockwool, NFT) tomatoes in Florida. Department of Horticultural Sciences, Florida Cooperative Extension Service, Institute of Food and Agricultural Sciences, University of Florida. http://edis. ifas.ufl.edu. (Accessed: June, 2008).

Incrocci, L., G. Fila, G. Bellocchi, and A. Pardossi. 2006. Soil-less indoor-grown lettuce (Lactuca sativa L.): Approaching the modelling task. Environmental Modelling \& Software. 21:121-126.

Kratky, B., and H. Mishima, 1981. Lettuce seedling and yield response to preplant and foliar fertilization during transplant production. J. Amer. Soc. For Hort Sci. 63:309-319.

Leskovar, D. I., S. Goret, J. L. Jifon, S. Agehara, T. Shinohara, and D. Moore. 2008. ABA to Enhance
Water Stress Tolerance of Vegetable Transplants. Acta Hort. 782:253-263.

Martínez, P.F. y M. Abad. 1992. Soilless culture of tomato in different mineral substrates. Acta Horticulturae 323: 251-259.

Montgomery, D. 1991. Diseño y Análisis de Experimentos. Grupo Editorial Iberoamérica. México DF, México.589 pp.

Molyneux, C. 1988. Theory of Nutrient Film Technique. A Practical Guide to NFT. Nutriculture Ltd. (ed.). Lancashire, Inglaterra.153 pp.

Nicola, S., J. Hoeberechts, and E. Fontana 2004. Studies on irrigation systems to grow lettuce (Lactuca sativa L.) transplant production and stand establishment. Acta Hort. 631:141-148.

Sharp, R. E. 2002. Interaction with ethylene: changing views on the role of abscisic acid in root and shoot growth responses to water stress. Pant, Cell and Environment. 25:211-222.

Tapia, M. L., P. Alvarado, and C. Barra. 2007. Crecimiento y desarrollo de plantines de tomate producidos en distintos volúmenes de alvéolos. Simiente 77(1-2): 17-31.

Tapia, M. L., P. Alvarado, and C. Navas. 2008. Efecto de diferentes volúmenes de alvéolo en la producción de plantines de brócoli, coliflor y repollo. Simiente (Chile) 78:27-43.

Vavrina, C. 2004. Transplant Production. Horticultural Sciences Department, Florida Cooperative Extension Service. IFAS Extension. University of Florida. http://edis.ifas.ufli.edu/pdffiles/CV/ CV10400.pdf. (Accessed: June, 2008).

Waine, L. 2003. El uso de almácigos en la producción de hortalizas. Division of Agriculture and Natural Resources. University of California. http://anrcatalog.ucdavis.edu. (Accessed: July, 2008).

Wien, H.C. 1997. Transplanting. Páginas 37-67. In: H.C. Wien (ed.).The Physiology of Vegetable Crops. CAB International, Wallingford, Oxon, U.K. 662 pp. 
